University of Nebraska - Lincoln

DigitalCommons@University of Nebraska - Lincoln

Textile Society of America Symposium

Proceedings

$10-2020$

\title{
Shared Provenance: Investigating Safavid-Mughal Cultural Exchange Through Luxury Silks in the Sixteenth and Seventeenth Centuries
}

Nazanin Hedayat Munroe

Follow this and additional works at: https://digitalcommons.unl.edu/tsaconf

Part of the Art and Materials Conservation Commons, Art Practice Commons, Fashion Design Commons, Fiber, Textile, and Weaving Arts Commons, Fine Arts Commons, and the Museum Studies Commons

This Article is brought to you for free and open access by the Textile Society of America at DigitalCommons@University of Nebraska - Lincoln. It has been accepted for inclusion in Textile Society of America Symposium Proceedings by an authorized administrator of DigitalCommons@University of Nebraska - Lincoln. 


\title{
Shared Provenance: Investigating Safavid-Mughal Cultural Exchange Through Luxury Silks in the Sixteenth and Seventeenth Centuries
}

\author{
Nazanin Hedayat Munroe \\ naz@hedayat.us
}

This study introduces the possibility of reattributing a group of woven figural silks depicting the Khamsa (Quintet of epic poetry) from Safavid Iran (1501-1722) to Mughal India (1526-1761). The group is comprised of eleven different designs in multiple fragments illustrating scenes from two eponymous love stories from Medieval Persian poetry: "Layla and Majnun," and "Khusrau and Shirin." Through close examination of this group of figural silks attributed to Iran, this study contemplates the possibility that some of these textiles were instead created by Safavid weavers working in the Mughal realm. Textile specialists are rarely mentioned in consideration of the groups of Iranian elites who migrated from the Safavid Court in the sixteenth century seeking Mughal patronage, despite documentation in the Akbarnama (1590-1595) of the presence of Iranian and Central Asian weavers in the royal weaving workshops. ${ }^{1}$ A potential reattribution not only points out the significance of artisan immigrant populations in propagating certain techniques, but links these two cultures through a shared philosophy and identity represented by textiles and garments depicting these characters.

Safavid weavers were known throughout the early modern Persianate realm for creating silks with detailed designs resembling paintings, often with human and animal figures in foliated landscapes, known as figural silks. These can be loosely categorized into two sub-genres: those depicting idealized scenes, and those depicting specific scenes from Persian literature such as the Khamsa, referenced hereafter in this study as narrative silks. This group includes a scene depicting Layla and Majnun, two Bedouin youth separated by their families, meeting in the desert wilderness after the young man has quitted society as a result of his love-madness [earning him the moniker 'Majnun,' the crazed one]. The second group illustrates the initial meeting of Khusrau and Shirin, a royal couple whose tale includes a love triangle with the sculptor/engineer Farhad. Although there is some evidence for figural silks in the Iranian realm prior to the Safavid period, the corpus of extant examples studied here dates approximately to the period between 1550 and 1650, all attributed to Safavid Iran, and often further connected by scholars with medieval Persian-language poet Nizami Ganjavi (d. 1209). However, looking closely at the figural scenes, it became evident that there were some discrepancies in the iconography with regard to manuscript paintings depicting the same narratives in Nizami's poetry. ${ }^{2}$

The imagery in this group of silks, based on dating and other factors, correlates with paintings depicting the same scene. Although the relationship of painting and textile design is a larger

\footnotetext{
${ }^{1}$ The Akbarnama was written in Persian by Abu'l-Fazl 'Allami, the court historian of Mughal Shah Akbar (r. 15561605), documenting several aspects of the ruler's court and empire. See Abu'l-Fazl 'Allami, trans. Heinrich Blochmann Akbarnama (Calcutta: The Asiatic Society, 1873), A'in-i Akbari (Vol. III), A'in 31: The wardrobe and the stores for the mattresses.

${ }^{2}$ I have presented a thorough argument for the reattribution of some silks in this group in my doctoral dissertation. See Nazanin Hedayat Munroe, "Interwoven Lovers: Narrative Silks Depicting Characters from the Khamsa" (Ph.D. Diss., University of Bern, 2018).
} 
discussion outside the scope of this paper, the visual correlations are notable. Looking at a folio from an illustrated Khamsa of Nizami commissioned by Shah Tahmasp in 1524-5 (figure 1), we see one of most frequently illustrated scenes in the cycle of illustration for Khusrau and Shirin: the 'bathing scene' depicting the first meeting of the royal lovers. Simultaneously traveling across the Iranian plateau to find one another, the Sasanian king happens upon his beloved bathing nude in a stream. Although they have never met in person up to this point, the two recognize each other instantly, and this moment is key to illustrating the tumultuous love affair.

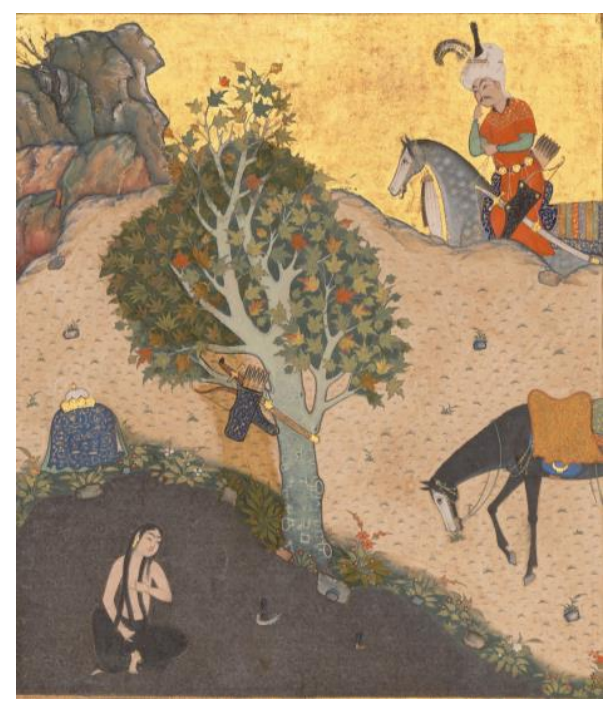

Figure 1 Khusrau Catches Sight of Shirin Bathing from a Khamsa of Nizami. Painting by Shaikh Zada.

1524-5, Herat (Safavid period).

The Metropolitan Museum (13.228.7.3)

Gift of Alexander Smith Cochran, 1913

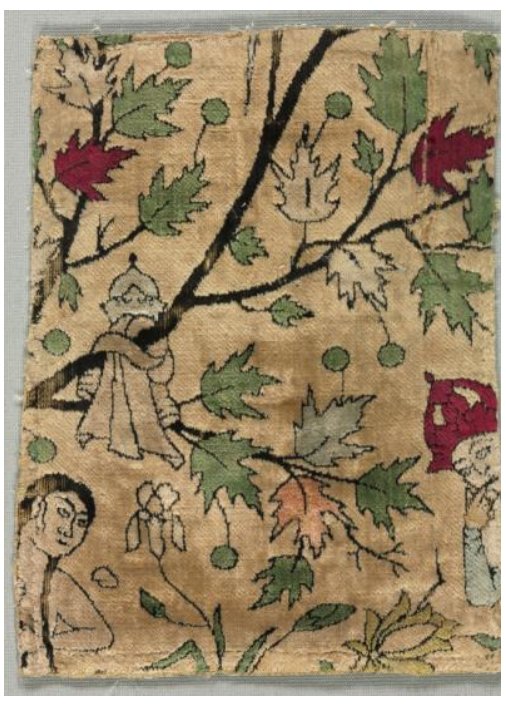

Figure 2a Velvet fragment with design from Khusrau and Shirin. 1550-1599. Silk; velvet, cut, pile warp substitution. Textile: $7.5 \times 5.875 \mathrm{in} .(19.1 \times 14.9 \mathrm{~cm})$ Cleveland Museum of Art (1944.499.b) Purchase from the J.H. Wade Fund.

Figure $2 \boldsymbol{b}$ (far right) Textile depicting Khusrau and Shirin. Silk; cut velvet. Attributed to Iran, $16^{\text {th }}$ c. Textile: 15.375 in. $x 6.5$ in $(39 \times 16.5 \mathrm{~cm})$ The Metropolitan Museum (1978.60) Purchase, The Seley Foundation Inc., Schimmel Foundation Inc., Ruth Blumka and Charles D. Kelekian Gifts, and Rogers Fund, 1978

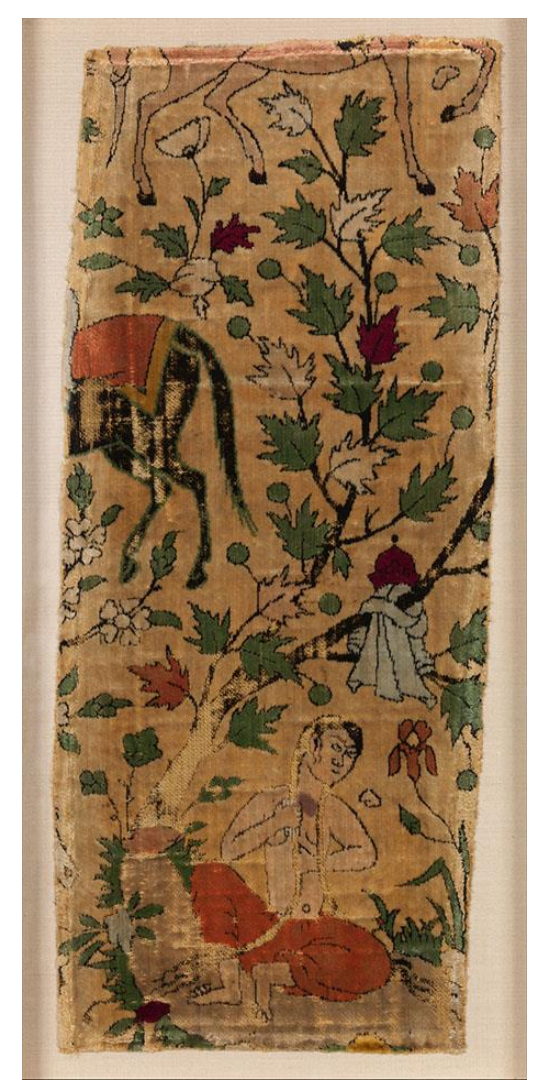

There are four silk designs in total depicting this scene, each of them rendered with Khusrau on his horse watching a partly-nude Shirin washing her hair (figures $2 \mathrm{a}$ and $2 \mathrm{~b}$; fragments of the same design). The scene is reproduced with similar iconographic details in different techniques: three designs are executed in velvet, two of which include voiding; the final design is executed in double cloth. ${ }^{3}$ Two of the three velvets include metal-wrapped threads, indicating a high level of patronage. One design is signed Amal-e Ghiyath or "Work of Ghiyath," noted in primary sources as a Safavid naqshband (textile designer) from Yazd, Iran active in the sixteenth century (ca. 1530-1593-5). ${ }^{4}$ The details that define this scene are quite consistent between manuscript and silks, although the composition was altered to accommodate repeat sequences on the loom.

\footnotetext{
${ }^{3}$ For a list of Khamsa textiles, see Munroe Interwoven Lovers, 2018, Appendix A.

${ }^{4}$ This is only one known signed version of a Khusrau and Shirin design; fragments reside in the Keir Collection (K.1.2014.44), currently on loan to the Dallas Museum of Art; The Textile Museum (3.318); and Montreal Museum of Fine Arts (1950.51.Dt.20).
} 
Textiles depicting Layla and Majnun, however, reflect less continuity between textiles and paintings with regard to the details of Nizami's narrative scene. In his tale, the lovers are separated and Majnun ventures alone into the wilderness. Album drawings and manuscript illustrations from Nizami's Khamsa depict him half-nude in a disheveled state, surrounded by wild animals who have befriended him. This scene is reproduced in a rather straightforward way in a velvet attributed to mid- $16^{\text {th }} \mathrm{c}$. Safavid production, fashioned as a chasuble and residing in The State Hermitage Museum (IR-2327). However, other scenes depicting Layla and Majnun in the wilderness do not correspond with Nizami's Khamsa. Two silks in particular, also signed Amal-e Ghiyath, both show Layla venturing to Majnun in the wilderness in her palanquin atop a camel, in one example led by a servant (figure 3). This meeting between the lovers never actually takes place in Nizami's tale, but instead, seem to be depicting a scene from a different Khamsa: that of Amir Khusrau Dihlavi, a $14^{\text {th }}$ c. Turco-Hindu poet working for the sultan Ala al-Din in Delhi, who penned his own version of the famous love stories in Persian over a century later (1298-1302). Although Nizami's Khamsa is illustrated more often than Amir Khusrau's version, ${ }^{5}$ we see both versions being reproduced in illustrated MS across the Persianate realm.

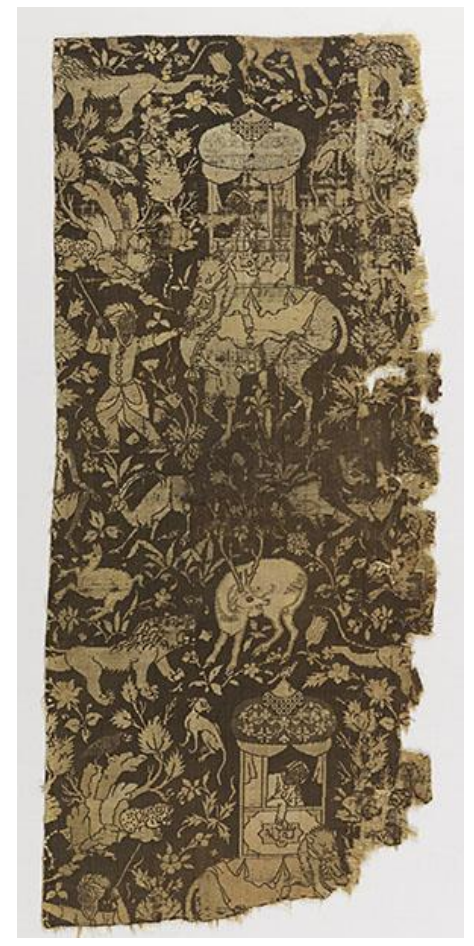

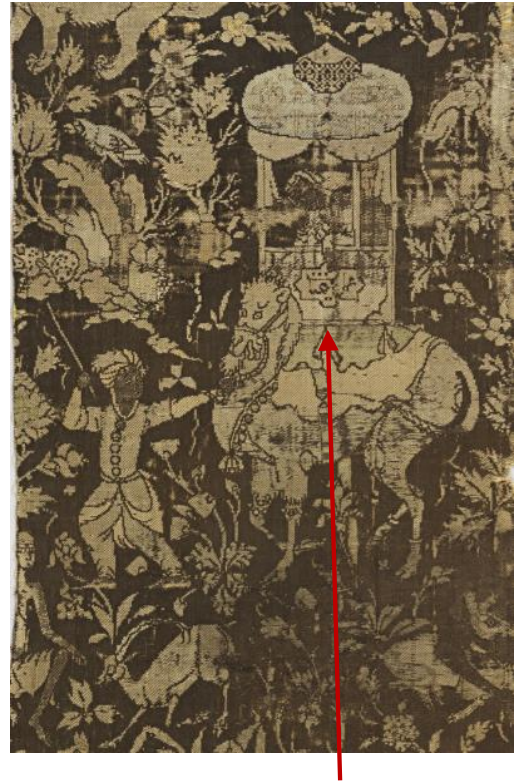

Textile signed: "Work of Ghiyath" Persian script:

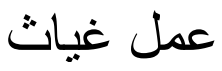

Figure 3. Textile depicting Layla and Majnun. Silk, gilded parchment wrapped around silk core, with detail. $253 / 16$ in. $x 11$ in $(64 \times 28 \mathrm{~cm})$ The Cooper-Hewitt SI (1902-1-780). Gift of John Pierpont Morgan.

Note: The Cooper-Hewitt does not list attribution of origin on its web site; another fragment of the same design in the Museum of Fine Arts Boston (28.17) lists Iran.

The Mughal atelier of Emperor Akbar (r. 1556-1605) produced illustrated copies of the Khamsa of both Nizami and Amir Khusrau, each of which includes a Wilderness scene in the tale of

\footnotetext{
${ }^{5}$ Following the Shahnama of Ferdowsi and the Khamsa of Nizami, Amir Khusrau's Khamsa is the most often illustrated epic poetry from the Islamic world. See Barbara Brend, Perspectives of Persian Painting: Illustrations to Amir Khusrau's Khamsah, (London: Psychology Press, 2003), xxiii.
} 
Layla and Majnun. However, there is a clear visual parallel between paintings and textiles in the scene of Amir Khusrau's work ${ }^{6}$ (figure 4). Considering that some of the Khamsa silks seem to correlate to the narrative and illustrations of Iranian poet Nizami's versions, and others to the versions of the Indian poet Amir Khusrau, this brings up questions about the place of manufacture for these early modern silks. Perhaps if there is a fluid connection between these two Khamsa manuscripts, whose texts are referenced interchangeably, there may also be a tangible connection for silk production in India and Iran. ${ }^{7}$

Certainly, by the early modern period, there was a diaspora of Iranian craftsmen and nobles in South Asia. Sanjay Subrahmanyam's study “Iranians Abroad: Intra-Asian Elite Migration and Early Modern State Formation" posits that the migration of the Muslim Iranian elite began perhaps as early as the Ghaznavid period (977-1186), citing the system of governance of the Delhi sultanates as being based on the Iranian model of administration. ${ }^{8}$ By the late medieval period, Turco-Mongol traditions including Turkish dialects, dynastic succession, and burial rituals also played heavily into the cultural elements of court life in India. ${ }^{9}$ The fifteenth century migration accompanying the establishment of the Bahmani sultanate (1347-1489) brought the essential elements of Iranian culture to India and the surrounding regions almost two centuries before the Mughal conquest. Although Suhbramanyam's focus here is the general migration of "elite" Iranians, this includes a broad spectrum including merchants and high-ranking administrators, and it follows that both these groups would need artisans to produce textiles for domestic and export markets. ${ }^{10}$ During the Mughal period, the migration of Iranians continued, presenting financial opportunities as well as spiritual freedom-particularly in the decade following the regime change and power vacuum at the end of Tahmasp's 52-year reign (15241576). ${ }^{11}$

\footnotetext{
${ }^{6}$ There is a general consensus in the history of Mughal visual arts that painting that it was largely shaped by migration of two significant artists from the royal atelier of Safavid Shah Tahmasp, Mir Sayyid Ali and Abd asSamad who were brought to India by Humayun in 1553-4. However, this painting is clearly imbued with aesthetic qualities found in Hindu paintings, particularly representations of ascetics, indicating a syncretism in painting perhaps lending itself to textile design.

${ }^{7}$ I was cognizant of not taking an ethnocentric approach by assuming that all the Amir Khusrau silks were from India and that Nizami silks were from Iran; it's obviously more nuanced than this. However, this was my starting point for the connection between these two cultures.

${ }^{8}$ Subrahmanyam corroborates earlier scholars who state that the Iranian model of governance in India was based on the Sasanian [pre-Islamic] model. See Sanjay Subrahmanyam, "Iranians Abroad: Intra-Asian Elite Migration and Early Modern State Formation,” The Journal of Asian Studies Vol. 51, No. 2 (May 1992), 342.

${ }^{9}$ It should be noted that the modern-day borders separating Iran and Central Asia (Uzbekistan, Kazakhstan, Kyrgyzstan, Tajikistan, Turkmenistan; extending to Mongolia in the east) are not reflective of the dynastic boundaries of the medieval and early modern eras. Therefore, it was quite common to see a cultural blending of Iranian and Turco-Mongol traditions within these regions, later transported with immigrants to South Asia.

${ }^{10}$ Subrahmanyam writes: "the Bahmanis of the early fifteenth century sought to import soldiers, administrators, traders, and artists from the Persian Gulf, and Firuz Shah is reported actually to have sent empty ships to Hurmuz and other ports to bring back this precious human cargo.” Subrahmanyam, Iranians Abroad, 342.

${ }^{11}$ Sheila Canby, Shah 'Abbas: The Remaking of Iran (London: The British Museum Press, 2009), 15-16. Canby notes that the reigns of Ismaill II (r. 1576-7) and Muhammad Khudabanda (r. 1577-87) resulted in a power struggle between the Qizilbash [Turcoman] administrators and the Safavid ruling family, who were descended from the fourteenth century Sufi shaykh, Safi al-Din. This political unrest contributed to the migration of noblemen and other groups.
} 
Primarily these immigrant groups had migrated eastward across Asia seeking spiritual and religious freedom as Sufis [Islamic mystics] to join the socially and politically powerful Naqshbandi order. ${ }^{12}$ Sufism attracted a wide variety of adherents, from landowning gentry to the working class, as well as craftsmen of "performing professions" and "implement professions."13 In Sufism, the ultimate goal is to find spiritual union with the Beloved [God]; this is often described in Islamic terms as conquering the nafs (carnal soul), achieved by separating oneself with the physical and material world in order to experience tawhid (oneness with God), taking on the characteristics of the Divine. This is obtained through practice with a group of like-minded individuals by joining a tariqa (Sufi brotherhood or order) under the tutelage of a pir (master), who helped novices progress through various levels of development. Two contrasting approaches were developed to this end. The first is a path of asceticism and removal from society, resulting in the "wandering dervish" who spent his days performing zikr (remembrance), a form of chanting to attain a meditative state. ${ }^{14}$ The second-geared towards artisans-was the path of the Sufi living and working within society, owning and producing material objects while practicing the faith inwardly by applying a spiritual interpretation of Sufi concepts.

This spiritual interpretation of the craft professions was outlined in several handbooks for the aspiring Sufi throughout the late medieval and early modern periods. ${ }^{15}$ The fifteenth and sixteenth centuries witnessed the authorship and proliferation of the futuwwat-nama, a genre of literature outlining proper behavior and ethics for Sufis. ${ }^{16}$ The Futuwwat-nama-yi Sultani (Royal Book of Chivalry) by Husayn Vaiz-i Kashifi (1436/7-1504/5) specifically outlines the spiritual element in object making, including textiles, indicating how the practice of spirituality could be embedded in the practice of the applied arts. Kashifi stresses the importance of contributing to society, but not being attached to worldly possessions, and worshiping inwardly through the practice of one's craft. ${ }^{17}$ For these Sufi artists, spirituality in practice manifested itself through the use of visual symbolism, derived from poetry popular among Sufi believers, including scenes from popular literature.

\footnotetext{
12 Subrahmanyam, "Iranians Abroad," 342. In addition to the Naqshbandi order, Sufi groups politically wellconnected during the fifteenth century in India include the Chishti order. The Chishtis developed a strong foothold from the late medieval period in the regions that would come to be ruled by the Mughal dynasty, later developing personal relationships with the Mughal ruling family and playing a critical rule in the politics during the latter half of the sixteenth and early seventeenth centuries.

${ }^{13}$ Arley Loewen, "Proper Conduct (Adab) is Everything: The Futuwwat-nama-i Sultani of Husayn Va'iz Kashifi," Iranian Studies Vol. 36, No. 4 (December 2003), 564.

14 The term darvish has made its way into English as 'dervish'. In medieval and early modern Persian sources, this is used interchangeably with fakir (poor person); the 'wandering dervish' often maintained few material possessions, but the connotation of poverty implied in the language is more likely metaphorical, as an expression of the spiritual state of the Sufi adherent.

${ }^{15}$ Designed as a handbook for daily life, some of these works were specifically intended for the artisans who were practicing Sufis.

${ }^{16}$ These are also known as books of jawanmardi (chivalry). The first documented futuwwat-nama dates to the medieval period, authored by Umar Suhrawardi (d. 1234). In Iran specifically, the first futuwwat-nama was authored by Najm al-Din Zarkub Tabrizi (d.1313), a descendent of Suhrawardi. See Loewen, 543-4, n. 3 and 5.

${ }^{17}$ It should be noted that Kashifi is concerned with outlining an idealized lifestyle for artisans, rather than a reflection of actual practices in his time, which he laments as unbecoming to the ideal of the chivalrous man. The final two chapters of the work are devoted to Sufi professionals in the visual arts, perhaps with the goal of edifying them.
} 
The Khamsa - both Nizami's version authored in the late twelfth century, and Amir Khusrau's version one hundred years later - is one of the most celebrated poetic works of Persian language, and as such, was well known among the educated elite. The two male protagonists in the figural silks, Majnun and Khusrau, ultimately represent the two paths of Sufism, that of the ascetic and that of the Sufi in society. This link of artisans to the Naqshbandi order may have fostered admiration for the Majnun character, who by the fifteenth century had become a representation for the Sufi dilemma: separation and union of the earthly beloved was a metaphor of separation from the Divine Beloved. In both literary references and depictions, Majnun becomes a symbol for the Sufi seeking enlightenment by denouncing the world. He is depicted in the Khamsa silks as being in a wilderness surrounded by animals, indicating his removal from society.

Presumably the wearer, as well as the viewer, would have been able to identify the scenes based on a shared recognition of the narratives and their symbolic significance. ${ }^{18}$ However, returning to the relationship of figural silk textile design to painting, it is still unclear who designed the imagery of the silks. Based on the high level of skill required to design these detailed textiles, the final thread models were most likely designed by a naqshband who perhaps used a drawing by a painter (or created his own), although primary sources have yet to be uncovered regarding this exact practice. It seems clear that there is a relationship between these two disciplines, indicating a shared iconography and aesthetic. Based on this visual correlation, textile scholars have been relying on manuscript illustration to determine the date and provenance of these textiles, but this may not be the most accurate determination. In practice, textile designers relying on manuscript illustrations for iconographic details could choose examples from any time period up to their present day, so it's possible that even a close visual match between a textile and a painting could represent a large chronological gap in production dates. ${ }^{19}$ This leads to the question of dating: although 1550 to 1650 is a plausible range, one has to look at iconographic details to narrow it down further within that time period.

The shape of larger extant Khamsa silk fragments, such as a red double cloth at the CooperHewitt museum (1902-1-379), indicate that at least some of these seem to have been fashioned into garments, whereas others are too fragmented and small to determine (figure 5). However, examples of garments made from other types of figural silk demonstrate the end use of this type of textile, such as the figural silk garment gifted by Mughal ruler Jahangir to his father-in-law, known as the Bikaner coat (ca. 1595).

Another example of a figural silk garment is evident in the painting of four courtiers (figure 5) at the Mughal court of Jahangir, from the Shah Jahan album; in the upper right is a portrait of Inayat Khan, who is wearing red figural silk trousers (ca. 1610) and holding an object wrapped in a differing figural silk with a gold ground. A second example in the same anthology at The Metropolitan Museum (55.121.10.36) shows figural silk that has been fashioned into a bolster for the future Shah Jahan in a painting dated 1620. Requiring a high level of skill, these silks were

\footnotetext{
${ }^{18}$ I have considered the symbolism of the Layla and Majnun textiles in two previous works published under my former name, Nazanin Hedayat Shenasa: Donning the Cloak: Safavid Figural Silks and the Display of Identity (Master's Thesis, San Jose State University: 2007); and in an abbreviated publication by the same title for the Textile Society of America conference proceedings (2008).

${ }^{19}$ The Hermitage velvet of Majnun (IR-2327) attributed to mid-16 ${ }^{\text {th }}$ c. Iran, for example, includes a larger scale for the figure that paintings dated to the same time period and location. See Munroe "Interwoven Lovers" 2018, 112.
} 
clearly prized in Mughal India in the early modern period. However, there is little evidence indicating who designed and wove these textiles, and whether they were imported or gifted from Safavid Iran or created in India by Iranian weavers. ${ }^{20}$
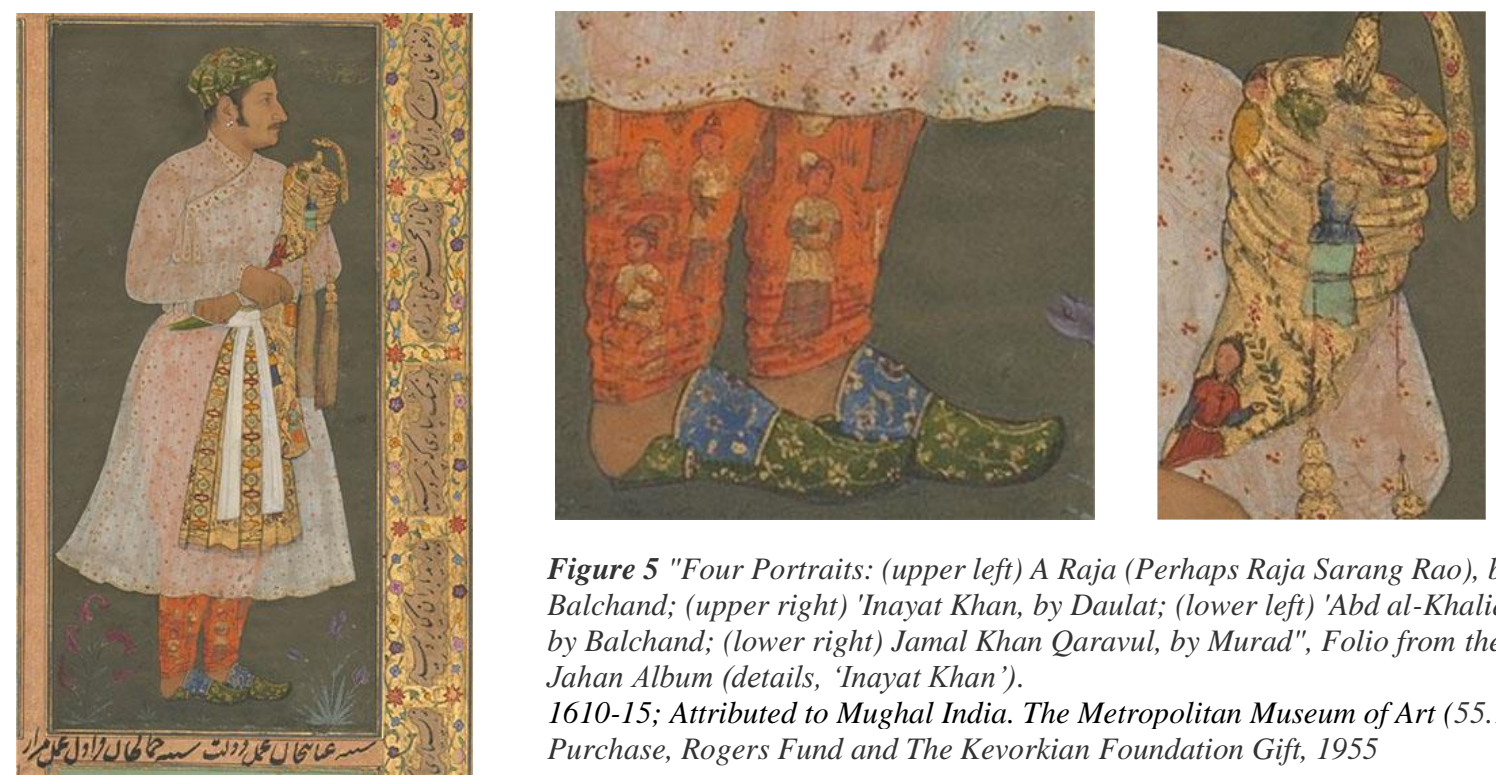

Figure 5 "Four Portraits: (upper left) A Raja (Perhaps Raja Sarang Rao), by Balchand; (upper right) 'Inayat Khan, by Daulat; (lower left) 'Abd al-Khaliq, probably by Balchand; (lower right) Jamal Khan Qaravul, by Murad", Folio from the Shah Jahan Album (details, 'Inayat Khan').

1610-15; Attributed to Mughal India. The Metropolitan Museum of Art (55.121.10.29) Purchase, Rogers Fund and The Kevorkian Foundation Gift, 1955

The Sufi connection is highly significant in connecting India and Iran in this period--particularly through the Naqshbandi order, which was at the height of spiritual and political power in the early modern period. Other connections include the Iranian Bahmani group, who migrated in the pre-Mughal, early Safavid period; these included many weavers and other craft-workers among them, as the Naqshbandi orders attracted this class of society. The presence of Sufis in India at the time of the establishment of the Mughal dynasty meant that the Sufi Shaykhs already had a strong presence in India, and were well-respected for their advice, even in political matters. ${ }^{21}$ It's entirely likely that weavers would also shape the themes of textiles being produced to reflect their own spiritual beliefs.

As far as the wearer or consumer of this type of narrative silk and a definitive end use, primarily men are depicted in figural silk - and none of the garments depicted are from the Khamsa group. ${ }^{22}$ Regardless of which Khamsa is used as the source for the narrative scene, some aspects of these characters are consistent across cultures: Majnun is a representation of piety and humility, and a role model for Sufis, while Khusrau is the representation of ideal kingship, a metaphor of the Sufi path of spirituality in practice through action. These two characters together

\footnotetext{
${ }^{20}$ For a discussion of Safavid figural silks at the Mughal court, see Sylvia Houghteling, "Sentiment in Silks: Safavid Figural Textiles in Mughal Courtly Culture," in Affect, Emotion and Subjectivity in Early Modern Muslim Empires, ed. Kishwar Rizvi (Leiden: Brill, 2018).

${ }^{21}$ See Richard Foltz, "The Central Asian Connections of the Mughal Emperors" in Journal of Islamic Studies (July 1996), 229-239.

${ }^{22}$ There are painted depictions of figural silk garments as early as 1550 . See the example "Young Prince" by Muhammad Haravi (F1937.8) in the National Museum of Asian Art, Smithsonian Institution [formerly the Freer Gallery of Art \& Arthur M. Sackler Gallery]. This depicts a 'prisoner' textile, another sub-genre of figural silks, and is corroborated by several extant fragments. For a study of the whole group, See Mary Anderson McWilliams, "Prisoner Imagery in Safavid Textiles," in The Textile Museum Journal, Vol. 26 (1987), 4-23.
} 
represent the ideal inner and outer selves for the ruling class and the elite. Despite the lack of pictorial evidence for women wearing figural silks, the female characters also serve as role models for viewers: Layla and Shirin are both idealized versions of the chaste and loyal beloved.

Ultimately, it may be the technical details that help determine provenance for this group of silks. Weave structures for textiles with Khamsa imagery includes double cloth, lampas and velvet, also indicating a range of price points for the cloth. ${ }^{23}$ Research conducted in the past decade has created a framework for potentially determining provenance for early modern textiles attributed to Mughal and Safavid workshops based on weave structure. Rahul Jain's 2011 study on technical properties of woven textiles in the series Mughal Velvets in the Calico Museum contributes significantly to identifying technical construction methods for Safavid, Mughal, and Ottoman silk velvets, highlighting the differences between them. ${ }^{24}$ Other technical details have been studied to develop a system for determining provenance as well: a 2015 study at The Metropolitan Museum of Art by Shibayama et al. looks closely at natural dyes and metalwrapped threads in textiles from both cultures, concluding that although there are some definitive materials and techniques in silks confirmed to be of Safavid or Mughal patronage, many of the technical details and materials overlap. ${ }^{25}$ Considering that master craftsmen are documented as migrating to India from Iran and other locations as early as the fourteenth century, bringing their techniques with them, how is it possible to identify the provenance of these textiles? Even if we are looking at what appears to be "Safavid" weave structure, it is difficult to know that these weren't created in Mughal India (or even pre-Mughal India) by Iranian weavers who came during the Safavid period, or perhaps earlier. It is clear that these two cultures had a shared philosophy and aesthetic, but it is apparent that even technical aspects of woven silks are not definitive in attributing figural designs to one or the other.

These Iranian immigrant weavers surely left a legacy, as evident in a Mughal figural velvet at the Los Angeles County Museum of Art (figure 6). This velvet panel, depicting confronting and addorsed women in Indian dress, was first identified as Mughal by curator Mary Kahlenberg based on its iconography, and more recently confirmed as such by Rosemary Crill in Fabric of India (2016) based on technical criteria set forth by Jain. ${ }^{26}$ Crill posits that Gujarati velvet drawloom velvet weaving was introduced to Indian weavers by Iranians ${ }^{27}$; however, if Jain's structural distinctions hold true, this would indicate that Iranians introduced a certain weave structure (generally a 5/1 satin ground, with pile warp channels following every 6 warp ends),

\footnotetext{
${ }^{23}$ Within this range of structures producing the Khamsa silks, the most expensive/valuable would be cut velvet followed by satin lampas and then double cloth; any silks produced with the addition of metal-wrapped threads would add to its value significantly, based on the type of metal (gold v. silver) and amount employed.

${ }^{24}$ Rahul Jain, Woven Textiles: Technical Studies Monograph No. 2 in the series Mughal Velvets in the Collection of the Calico Museum of Textiles (Ahmedabad: Sarabhai Foundation, 2011). Jain identifies the major differences of these three silk-producing cultures based on weave structure using diagrams.

${ }^{25}$ Shibayama et al. "Analysis of Natural Dyes and Metal Threads used in $16^{\text {th }}-18^{\text {th }}$ century Persian/Safavid and Indian/Mughal Velvets by HPLC-PDA and SEM-EDS to Investigate the System to Differentiate Velvets of these Two Cultures" in Heritage Science 3:12 (2015).

${ }^{26}$ Mary Kahlenberg, Fabric and Fashion: Twenty Years of Costume Council Gifts (Los Angeles: Los Angeles County Museum, 1974), cat. No. 14; and Rosemary Crill, Fabric of India (London : V \& A Publishing, 2015), pl. 69. Crill reattributes another figural velvet (pl. 67), previously attributed to Safavid Iran, as Mughal based on technical criteria.

${ }^{27}$ Crill, Fabric of India, 60.
} 
which was then adapted and revised by local weavers. ${ }^{28}$ Despite examples such as this panel and a few others attributed as Mughal with regard to patronage, the penchant for figural design is more consistently attributed to Iranian design; in other words, even if produced in a Mughal manufactory, the style in this velvet still retains elements of Safavid figural silks.
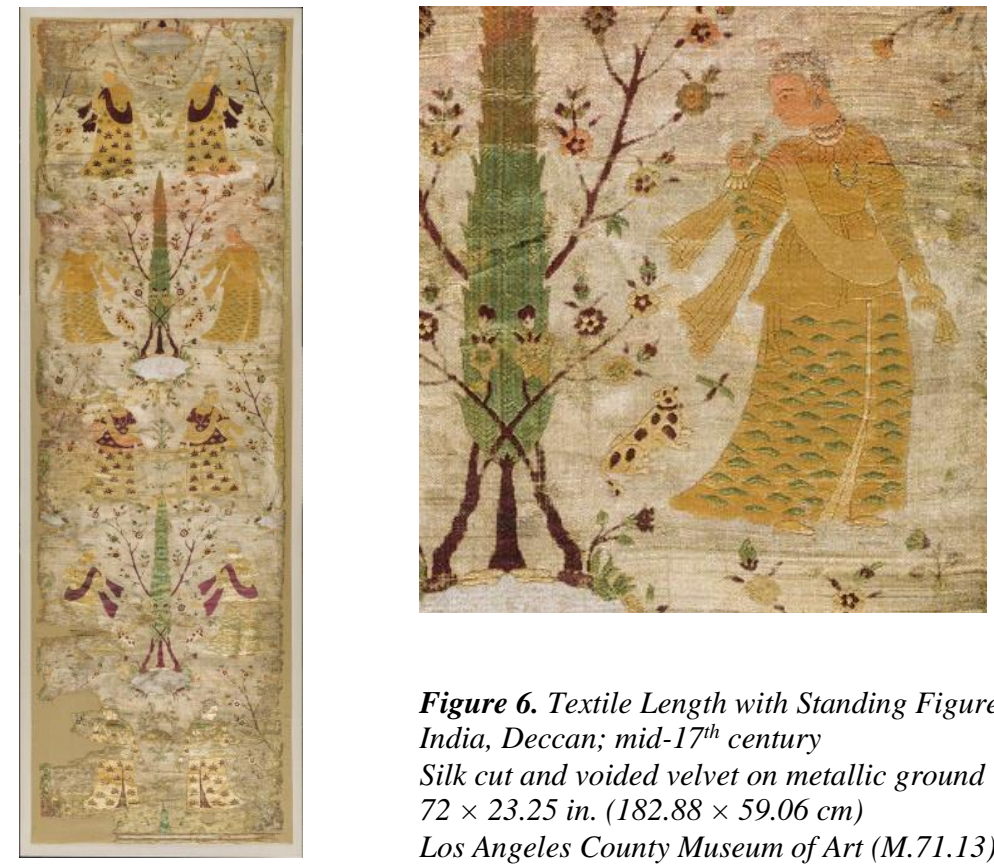

Figure 6. Textile Length with Standing Figures (with detail, right) India, Deccan; mid-17 $7^{\text {th }}$ century Silk cut and voided velvet on metallic ground $72 \times 23.25$ in. $(182.88 \times 59.06 \mathrm{~cm})$

Los Angeles County Museum of Art (M.71.13) Costume Council Fund

Given the absorption of Iranian craftsmen into the royal atelier of Akbar, who set up karkhanas (workshops) across his realm, how is it possible to dismiss the possibility that these silks were produced in the Mughal realm by Iranian naqshband, and how would we then classify the provenance for these objects if this is the case?

In consideration of textiles produced by immigrant weavers and other specialists, additional questions apply with regard to classifying these objects and their makers. How does a diaspora community identify itself, and how long must they reside in a new location before being fully absorbed as a member of the local community? Primary sources indicate that Iranian immigrants are still considered 'Iranian' even three or four generations after they have migrated to other locations. This is even more extreme in the example of Sufi shaykhs from Bukhara, Central Asians who settled in the Indian subcontinent in the sixteenth and seventeenth centuries, who are still identified as such in their adopted homeland even five or six generations following their migration. ${ }^{29}$ Additionally, how do we identify works produced by diaspora artists/craftsmen? Do we reference the artist's identity, or the location of manufacture? How do artists and immigrants in general identify themselves, and how does the indigenous population view them?

\footnotetext{
${ }^{28}$ See Jain, Woven Textiles, 9. Based on my studies, alternate ground weaves for velvet include 8/1 satin or 4/1 twill. ${ }^{29}$ Richard Foltz, "The Central Asian Connections of the Mughal Emperors" in Journal of Islamic Studies (July 1996), 239.
} 
Broadening the perspective of what elements inform identity in the early modern context, it becomes evident based on primary source material that immigrants seemed to retain their originlocale for several generations, mostly through name-place affiliations such as 'Shirazi' or 'Isfahani' [Iranian cities]. However, identity was a layered concept: an Iranian émigré in Mughal India was perhaps first Iranian, and Muslim; perhaps belonging to a specific Sufi order like the Naqshbandi; an artisan member of a guild, or other profession; as well as a citizen of the Mughal empire, working for the ruler or contributing to the national economy in some capacity. All these elements are equally important to the cross-cultural exchange evident during the early modern era, and especially at the Mughal and Safavid courts. These are questions that hopefully textile experts, as well as art historians and other material culture scholars, will contemplate and contextualize in the future.

In conclusion, the Khamsa silks may have been produced in different parts of the Islamic world, but potentially by the same group of designer/weavers, creating questions about how we identify craftsmen working in the diaspora. In the case of Iranian textile specialists who migrated to the Indian subcontinent and its surrounding area, weavers and designers left a legacy that informed local production. Identifying cultural objects in the modern and postmodern eras has been more centered on patronage, and the identity of the ruling class in the location of manufacture. Ultimately, this practice also masks the contributions of immigrants involved in textile production, who in many cases remain forgotten. 


\section{Bibliography}

'Allami, Abu'l-Fazl. Akbarnama. Translated by Heinrich Blochmann. Calcutta: The Asiatic Society, 1873.

Brend, Barbara. Perspectives of Persian Painting: Illustrations to Amir Khusrau's Khamsah. Psychology Press, London: 2003.

Canby, Sheila. Shah 'Abbas: The Remaking of Iran. The British Museum Press, London: 2009.

Crill, Rosemary. Fabric of India. London: V \& A Publishing, 2015.

Foltz, Richard. "The Central Asian Connections of the Mughal Emperors" in Journal of Islamic Studies (July 1996), 229-239.

Houghteling, Sylvia. "Sentiment in Silks: Safavid Figural Textiles in Mughal Courtly Culture." In Affect, Emotion and Subjectivity in Early Modern Muslim Empires, edited by Kishwar Rizvi, 124-147. Leiden: Brill, 2018.

Jain, Rahul. Woven Textiles: Technical Studies Monograph No. 2 in the series Mughal Velvets in the Collection of the Calico Museum of Textiles. Ahmedabad: Sarabhai Foundation, 2011.

Kahlenberg, Mary. Fabric and Fashion: Twenty Years of Costume Council Gifts. Los Angeles: Los Angeles County Museum, 1974.

Loewen, Arley. "Proper Conduct (Adab) is Everything: The Futuwwat-nama-i Sultani of Husayn Va'iz Kashifi." Iranian Studies Vol. 36, No. 4 (December 2003): 543-570.

Munroe, Nazanin Hedayat. "Interwoven Lovers: Narrative Silks Depicting Characters from the Khamsa." Ph.D. Diss., University of Bern, 2018.

Munroe, Nazanin Hedayat [formerly Nazanin Hedayat Shenasa]. "Donning the Cloak: Safavid Figural Silks and the Display of Identity." Textile Society of America: Conference Proceedings, 2008. https://digitalcommons.unl.edu/cgi/viewcontent.cgi?article=1133\&context=tsaconf

Nizami. Layla and Majnun. Translated by Rudolph Gelpke. New Lebanon: Omega Publications, 1997.

Subrahmanyam, Sanjay. "Iranians Abroad: Intra-Asian Elite Migration and Early Modern State Formation.” The Journal of Asian Studies, Vol. 51, No. 2 (May 1992): 340-363.

Shibayama, Nobuko, Mark Wypyski and Elisa Gagliardi-Mangilli. "Analysis of Natural Dyes and Metal Threads used in $16^{\text {th }}-18^{\text {th }}$ century Persian/Safavid and Indian/Mughal Velvets by HPLC-PDA and SEM-EDS to Investigate the System to Differentiate Velvets of these Two Cultures" in Heritage Science 3:12 (2015). 
